\title{
Angiotensin I converting enzyme in rat testis, epididymis and vas deferens under different conditions
}

\author{
G. Hohlbrugger*, H. Schweisfurth and H. Dahlheim
}

\author{
Department of Physiology, University of Munich, Pettenkoferstrasse 12, D-8000 Munich 2, \\ Federal Republic of Germany
}

\begin{abstract}
Summary. Angiotensin I converting enzyme (ACE) was found in the testis, epididymis and vas deferens of rats. In tissue specimens without a prior washout of seminal fluid the highest specific ACE activity was measured in the testis. The enzyme activity was significantly lower towards the end of the excurrent ducts, suggesting that the enzyme is synthesized in the testis and secreted into the seminal fluid there. An ACE inhibiting substance may be secreted by the epididymal epithelium. Enzyme synthesis and enzyme inhibition are probably under simultaneous endocrine control. In-vitro inhibition, $\mathrm{pH}$ - and temperature-dependence of gonadal ACE correspond with that of lung and blood plasma. However, the physiological function of the enzyme on sperm motility and fertility remains unsolved.
\end{abstract}

\section{Introduction}

Angiotensin I converting enzyme (ACE) is possibly a key regulatory component of two physiologically active substances, angiotensin II and bradykinin, both involved in regulation of blood flow (Elisseeva, Orechovich, Pavlikhina \& Alexeenko, 1971). It catalyses the formation of the vasoactive octapeptide angiotensin II from the decapeptide angiotensin I (Lentz, Skeggs, Woods, Kahn \& Shumway, 1956) and it has a high affinity to bradykinin, which is degraded by splitting off a dipeptide (Yang, Erdoes \& Levin, 1971) (EC 3.4.15.1).

In the rat, blood plasma and most of the tissues contain measurable ACE activity. High specific activities occur in lung and in segments of digestive tract, but the highest activities are in testis and epididymis (Cushman \& Cheung, 1971; Schweisfurth \& Dahlheim, 1978). The lungs of immature rats contain normal ACE concentrations but the activity of testes increases markedly during maturation in intact, but not in hypophysectomized, rats, suggesting an endocrine control of enzyme synthesis there (Cushman \& Cheung, 1971). In the epididymis the distribution and control of ACE has not been previously elucidated. During their transit through the ductus epididymidis spermatozoa develop and mature due to changes in composition of the seminal fluid caused by the resorptive and secretory activities of the epithelium lining the duct (Levine \& Marsh, 1971; Setchell, 1974; Hamilton, 1975; Voglmayr, 1975; Hohlbrugger, 1980). It is therefore likely that there would be regional variations in ACE activity, and specific ACE activity was measured within the tissues of the various regions of the male tract of rats. The prostate and coagulating gland do not possess measurable ACE activities (Cushman \& Cheung, $1971)$ and were not investigated. The influence of age and sexual stimulation due to mating was also studied and some in-vitro experiments were performed to characterize the enzyme.

* Present address: Universitätklinik für Urologie, Anichstrasse 35, A-6020 Innsbruck, Austria. 


\section{Materials and Methods}

Animals. Male Sprague-Dawley rats, born and raised in our laboratory on a standard diet and water ad libitum, were anaesthetized with 5-sec-butyl-5-ethyl thiobarbituric acid $(120 \mathrm{mg} / \mathrm{kg}$ body wt). The posterior vena cava was cannulated for exsanguination and $0.9 \%(\mathrm{w} / \mathrm{v}) \mathrm{NaCl}$ solution was injected via an aortic catheter to wash out the remaining blood, to avoid contamination of the tissues with plasma ACE. Specimens (Text-fig. 1) were taken with microscissors. Rete testis fluid ( $5 \mu \mathrm{l})$ was collected as described by Tuck, Setchell, Waites \& Young (1970). Luminal contents from the vas deferens were expelled under mild electrical stimulation of the cauda epididymidis into a microcapillary tube $(5 \mu \mathrm{l})$ inserted into the cut end (Back, Shenton \& Glover, 1974). The various age groups studied were immature ( $<1 \mathrm{month})$, pubertal (1-2 months) and mature (2-6 months). To study the effect of mating each mature male was caged with 3 mature females for 2 weeks before being killed.

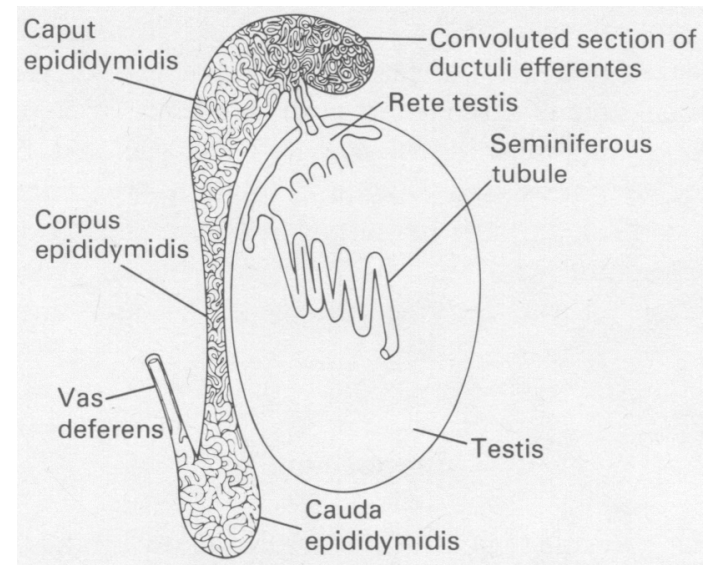

Text-fig. 1. Diagrammatic representation of sites from which samples were taken.

Sample preparation. Weighed specimens (about $3 \mathrm{mg}$ ) or luminal fluid ( $5 \mu$ l diluted with 500 $\mu \mathrm{l} 0.9 \% \mathrm{NaCl})$ were mechanically homogenized $(2 \times 1 \mathrm{~min})$ using a Potter Homogenizer, ultrasonically disintegrated $(15 \times 2 \mathrm{sec})$ with an HSE 100 Watt disintegrator, and then centrifuged for $1 \mathrm{~min}$ at about $12000 \mathrm{~g}$. The supernatant was separated and immediately used for ACE assay. All procedures were performed below $+4^{\circ} \mathrm{C}$ as quickly as possible.

Chemical analysis. ACE was measured using the method of Piquilloud, Reinharz \& Roth (1970) with the synthetic substrate $Z$-Phe-His-Leu $(Z=$ benzyloxycarbonyl), which is not hydrolysed by most other tissue peptidases. From this compound ACE splits off the dipeptide His-Leu, which is measured fluorometrically following its reaction with orthophthaldialdehyde. For this purpose, $10 \mu \mathrm{l}$ of the supernatant from the tissue preparation were mixed with borax phosphate buffer $(0.05 \mathrm{M}$-tetraborate, Merck) containing $1 \% \mathrm{NaCl}$ (final concentration). The mixture was incubated up to $60 \mathrm{~min}$ at optimal $\mathrm{pH}(8.0)$ and temperature $\left(37^{\circ} \mathrm{C}\right)$. Within this time, His-Leu formation was found to be constant.

Statistical evaluation. The data obtained were expressed as mean \pm s.e.m. Animals from the same litter or the same age group served as controls. The significance of differences was estimated by Student's $t$ test.

\section{Results}

Quantitative distribution, age dependence and sexual stimulation

The highest specific ACE activities of mature animals were measured in luminal contents from the vas deferens, which exceeded almost 3 -fold the levels in rete testis fluid. 
In the tissue specimens (without prior washout of luminal contents) ACE activity was highest in the testis and ductuli efferentes, which was in the range of the rete testis fluid. The corresponding values of caput, corpus and cauda epididymidis were similar to one another but significantly lower than in the testis and ductuli efferentes. The vas deferens had the lowest enzymic activity. No differences were detected between left and right sides. Immature animals had comparably small amounts in all gonadal structures investigated. With the onset of puberty, $\mathrm{ACE}$ increased markedly in the testis and ductuli efferentes and to a lesser extent in the more distal regions (Text-fig. 2).

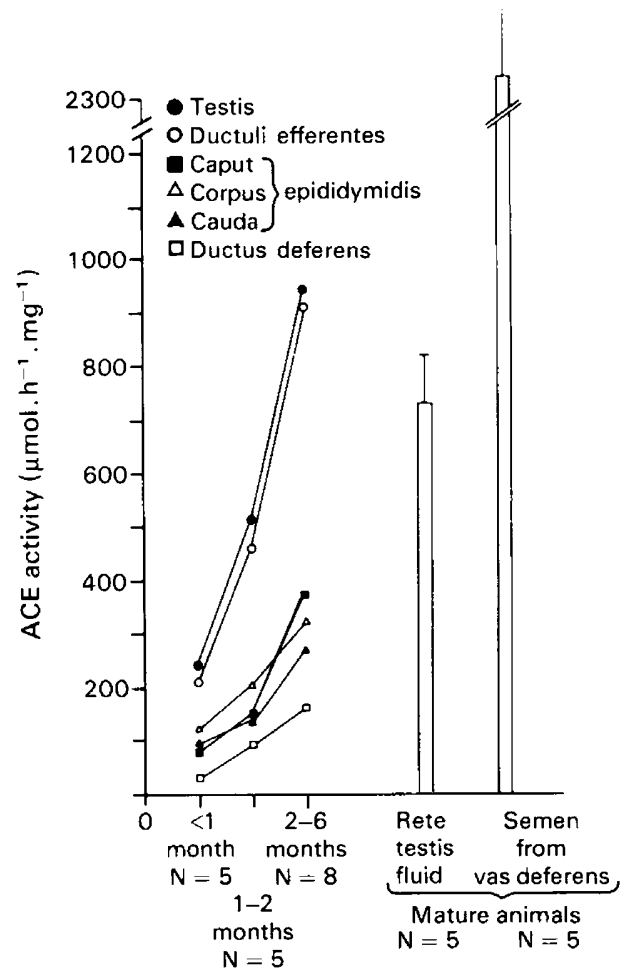

Text-fig. 2. Effect of age on ACE activity in different regions of the rat reproductive tract in comparison to ACE activity in seminal fluid of mature animals.

Sexual stimulation due to mating with females significantly increased ACE activity in the testis, ductuli efferentes and caput epididymidis of mature males. In the more distal regions the enzymic activity remained constant (Text-fig. 3 ).

\section{In-vitro characteristics}

pH. ACE activity was maximal at $\mathrm{pH} 8.0$ (Text-fig. $4 \mathrm{a}$ ). The $\mathrm{pH}$ was altered by addition of $\mathrm{NaOH}$ or $\mathrm{HCl}$ to the standard buffer solution. A change of $\mathrm{NaCl}$ concentration alone had only a negligible effect on the enzyme activity.

Temperature. Optimal ACE activities were obtained at about $37^{\circ} \mathrm{C} \mathrm{(Text-fig.} \mathrm{4b).}$

In-vitro inhibition. In-vitro inhibition was produced by the specific ACE inhibitor SQ 14225 with a $50 \%$ inhibition at $320 \mathrm{pg} / \mathrm{ml}$ (Text-fig. 5). 


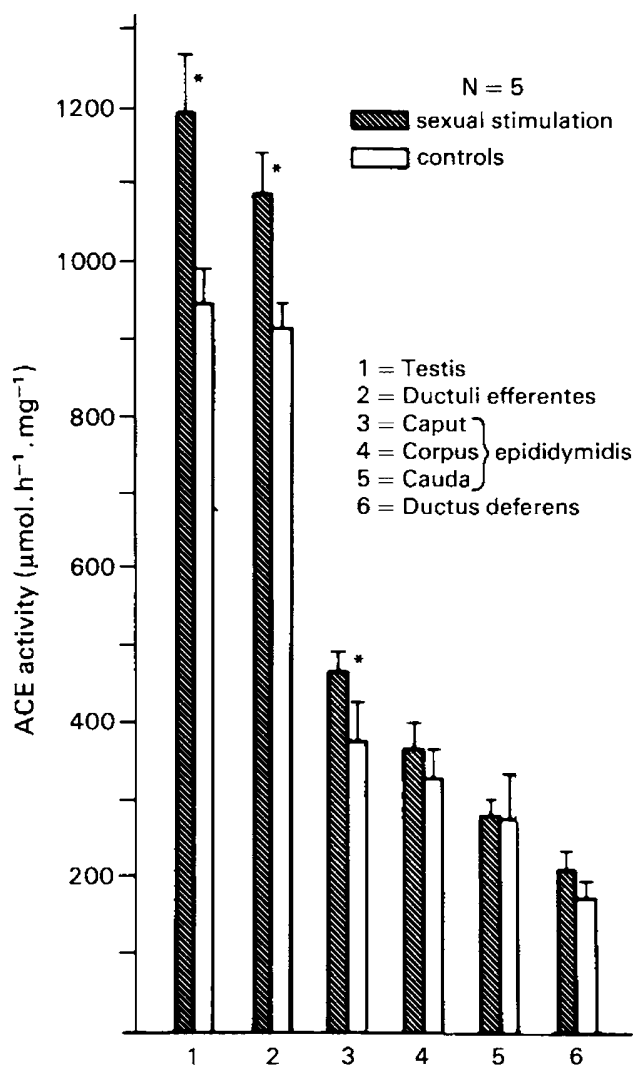

Text-fig. 3. Effect of sexual stimulation on ACE activity in different regions of the rat reproductive tract. ${ }^{*} P<0.01$.

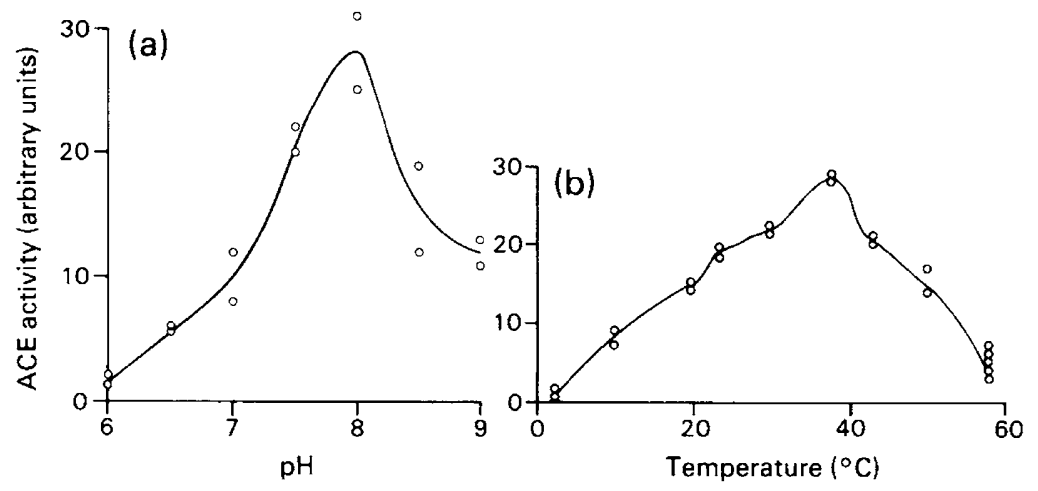

Text-fig. 4. The effect of (a) $\mathrm{pH}$ and (b) temperature on ACE activity of testicular homogenate $\left(10 \mu \mathrm{g} . \mathrm{ml}^{-1}\right.$ ) incubated for $60 \mathrm{~min}$ at $37^{\circ} \mathrm{C}$ (a) and $\mathrm{pH} 8 \cdot 0$ (b).

$K_{m}$ value. The $K_{\mathrm{m}}$ values were determined according to Lineweaver \& Burk (1934) using the synthetic substrate Z-Phe-His-Leu. A value of $36.9 \pm 17.4 \mu \mathrm{mol}(n=7)$ for gonadal ACE was significantly different from that of lung ACE $(86 \cdot 5 \pm 9 \cdot 3 \mu \mathrm{mol}, n=4)$.

The in-vitro experiments were performed with tissue specimens of all regions investigated and no regional variations were found. 


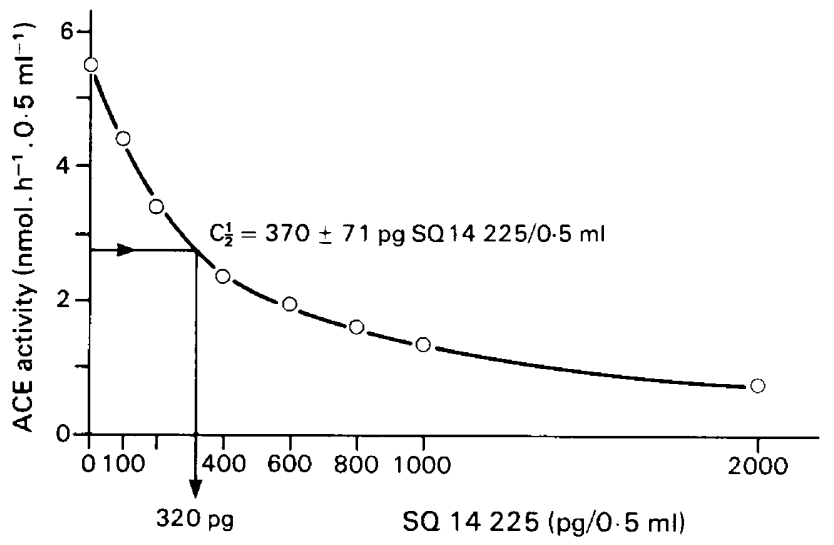

Text-fig. 5. The effect of the ACE inhibitor SQ 14225 on testicular ACE activity. Reaction conditions: testicular homogenate $20 \mu \mathrm{g} \cdot \mathrm{ml}^{-1} ; 37^{\circ} \mathrm{C} ; \mathrm{pH} 8.0$; incubation time $60 \mathrm{~min}$.

\section{Discussion}

The highest ACE activities in the tissue specimens of the testis without a prior washout of seminal fluid indicate that gonadal ACE is merely synthesized and secreted into the seminal fluid there. This was confirmed by the high activity in rete testis fluid and by the decreasing activity in the corresponding tissue specimens along the excurrent ducts. On the other hand, the seminal fluid of the vas deferens had almost 3-fold ACE levels when compared with those of the rete testis fluid and were about 14 times higher than those of the tissue specimens of the vas. This apparently conflicting finding can be explained by consideration of the resorptive and secretory activities of the epithelium lining the excurrent ducts. Micropuncture studies show that $46 \%$ water of the fluid formed in the seminiferous tubules is reabsorbed in the ductuli efferentes and in the initial segment of the epididymis and between 23\% (Levine \& Marsh, 1971) and 34\% (Howards, Johnson \& Jesse, 1975) in the more distal segments of the epididymis. Hence, a 3-6-fold fluid concentration can be calculated between rete testis and vas deferens. Therefore any fluid concentration exceeding the 3 -fold value means loss of enzymic activity during transit through the epididymis. Furthermore, the lower enzymic activity obtained from tissue specimens suggests that there is an ACE-inhibiting substance within the tissue, particularly within the epithelium of the excurrent ducts, which is liberated by the homogenization procedure and probably secreted into the seminal fluid under physiological conditions with increasing amounts towards the end of the excurrent ducts. Reabsorption of the enzyme in the epididymis is unlikely.

Gonadal ACE rises at the onset of puberty and as puberty is induced by changes in the hypothalamic-pituitary-gonadal axis (Grumbach, Roth, Kaplan \& Kelch, 1974), gonadal ACE synthesis is most likely to be under endocrine control (Resko, Feder \& Goy, 1968). This was further supported by the increase of $\mathrm{ACE}$ after mating which corresponds with increased serum testosterone levels (Herz, Folman \& Drori, 1969; Purvis \& Haynes, 1974; Dessi-Fulgheri, Lupo di Prisco \& Verdarelli, 1975; Kamel, Wright, Mock \& Frankel, 1977). Since the increase of ACE activity within the tissue specimens of the epididymis was comparably small at the onset of puberty and failed to occur after mating one might assume a simultaneous endocrine control of ACE inhibitor synthesis and secretion as it is known for other secretion products of the epididymis (Brooks, 1977; Wong \& Yeung, 1978; Schenck, 1980).

ACE has been purified from human seminal plasma (Depierre \& Roth, 1974), but the contribution of gonadal ACE or of its substrates to male fertility has not yet been clarified. One ACE substrate bradykinin is thought to be an important factor for sperm motility and spermiogenesis (Schill \& Haberland, 1974; Rohen, 1978). Intraperitoneally administered 
kallikrein, the enzyme involved in bradykinin formation, is concentrated in the epithelium of the epididymis in rats (Blasini et al., 1979). The other possible substrate of ACE, angiotensin I, has not been detected in human seminal plasma, whereas renin, the enzyme involved in the formation of angiotensin I, has been demonstrated in concentrations similar to those in blood plasma (Craven, Warren \& Symonds, 1981). This suggests that both possible substrates of gonadal ACE may be present in the male reproductive tract although the site of action for the enzyme is not known. As the enzyme is present in the ejaculate, even an action in the female genital tract must be considered.

According to the in-vitro inhibition, the $\mathrm{pH}$ - and temperature-dependence results, gonadal ACE corresponds with that of lung and blood plasma (Schweisfurth \& Dahlheim, 1978). The almost complete inhibition of ACE with the smallest amounts of the specific inhibitor SQ 14225 further ensured that ACE was specifically measured. Since the enzyme was not purified in this study and since the presence of proteins or inhibitors would influence the $\mathrm{K}_{\mathrm{m}}$ determination, the difference from the lung value could be attributed to non-specific side reactions rather than a difference of the enzyme character. Unfortunately, no information is available on the fertility of men treated for hypertension with SQ 14225 (Case et al., 1978) but it is not known whether this inhibitor would penetrate through the blood-testis barrier. If it does not, then it is not likely to affect the activity of the enzyme inside the seminiferous tubules. The temperature behaviour of gonadal ACE should be studied more thoroughly as the normal temperature of the scrotum is lower than $37^{\circ} \mathrm{C}$ (Harrison, 1975). The influence of $\mathrm{pH}$ on gonadal ACE may also be important, as the $\mathrm{pH}$ of the luminal fluid alters remarkably during its passage through the epididymis (Levine \& Marsh, 1971; Levine \& Kelly, 1978).

It is concluded that gonadal ACE is similar to that of lung and plasma and may be involved with the physiology of male reproduction in the rat. The search for the cellular site of gonadal ACE synthesis and the understanding of its physiological role remain for further investigations.

This work was supported by the "Deutsche Forschungsgemein-schaft". We thank Dr B. P. Setchell for his helpful comments on the manuscript.

\section{References}

Back, D.J., Shenton, J.C. \& Glover, T.D. (1974) The composition of epididymal plasma from the cauda epididymidis of the rat. $J$. Reprod. Fert. 40, 211214.

Blasini, R., Schmeller, M.L., Pfeiffer, Chr., WriedtLuebbe, I., Huber, P. \& Bluemel, G. (1979) Experimentelle Untersuchungen ueber die organspezifische Anreicherung von Kininogenasen im Hoden-Nebenhodenbereich. Andrologia 12, 199_ 205.

Brooks, D. E. (1977) The androgenic control of the composition of the rat epididymis determined by efferent duct ligation or castration. J. Reprod. Fert. 49, 383-385.

Case, D.B., Atlas, S.A., Laragh, J.H., Sealy, J.E., Sullivan, P.A. \& McKinstry, D.N. (1978) Clinical experience with blockade of the renin-angiotensinaldosterone system by an oral converting enzyme inhibitor (SQ 14 225, Captopril) in hypertensive patients. Progr. Cardiovasc. Dis. 21, 195-206.

Craven, D.J., Warren, A.Y. \& Symonds, E.M. (1981) Occurrence of active and inactive renin in human seminal plasma. Arch Androl. (in press).

Cushman, D.W. \& Cheung, H.S. (1971) Concentrations of angiotensin converting enzyme in tissues of the rat. Biochem. Biophys. Acta 250, 261-265.

Depierre, D. \& Roth, M. (1974) Purification of angiotensin converting enzyme from human seminal plasma. Experientia 30, 686.

Dessi-Fulgheri, F., Lupo di Prisco, C. \& Verdarelli, P. (1975) Effects of two kinds of social deprivation on testosterone and estradiol-17 $\beta$ plasma levels in the male rat. Experientia 32, 114-115.

Elisseeva, Y.E., Orechovich, V.N., Pavlikhina, L.V. \& Alexeenko, L.P. (1971) Carboxy-cathepsin-a key regulatory component of two physiological systems involved in regulation of blood pressure. Clin. Chim. Acta 31, 413-416.

Grumbach, M.M., Roth, J.C., Kaplan, S.L. \& Kelch, R.P. (1974) In The Control of the Onset of Puberty, pp. 115-166. Eds M. M. Grumbach, G. D. Grave \& I. E. Mayer. Wiley, New York.

Hamilton, D.W. (1975) Morphology and function of the epithelium lining the ductuli efferentes, epididymis and vas deferens. In Handbook of Physiology, Male Reproductive System, Vol. V, pp. 259-301. Eds R. O. Greep \& E. B. Astwood. American Physiological Society, Washington, D.C. 
Hatrison, R.G. (1975) Effect of temperature on mammalian testis. In Handbook of Physiology, Male Reproductive System, Vol. V, pp. 219-223. Eds R. O. Greep \& E. B. Astwood. American Physiological Society, Washington, D.C.

Herz, Z., Folman, Y. \& Drori, D. (1969) Testosterone content of the testis of mated and unmated rats. $J$. Endocr. 44, 127-128.

Hohlbrugger, G. (1980) Die Physiologie des Nebenhodens. In Physiologie und Pathophysiologie des Nebenhodens und der Samenblase, pp. 27-39. Eds Th. Senge, F. Neumann \& U. W. Tunn. Georg Thieme Verlag, Stuttgart.

Howards, S.S., Johnson, A. \& Jesse, S. (1975) Micropuncture and microanalytic studies of the rat testis and epididymis. Fert. Steril. 26, 13-26.

Kamel, F., Wright, W.W., Mock, E.J. \& Frankel, A.I. (1977) The influence of mating and related stimulation on plasma levels of luteinizing hormone, prolactin and testosterone in the male rat. Endocrinology 101, 421-429.

Lentz, K.E., Skeggs, L.T., Woods, K.R., Kahn, J.R. \& Shumway, N.P. (1956) The amino acid composition of hypertension I. J. exp. Med. 104, 183-191.

Levine, N. \& Kelly, H. (1978) Measurement of pH in the rat epididymis in vivo. J. Reprod. Fert. 52, 333-335.

Levine, N. \& Marsh, D.J. (1971) Micropuncture studies of the electrochemical aspects of fluid and electrolyte transport in individual seminiferous tubules, the epididymis and the vas deferens in rats. $J$. Physiol., Lond. 213, 557-570.

Lineweaver, H. \& Burk, D. (1934) Determination of enzyme dissociation constants. J. Am. Chem. Soc. $56,658-668$.

Piquilloud, Y., Reinharz, A. \& Roth, M. (1970) Studies on angiotensin converting enzyme with different substrates. Biochim. Biophys. Acta 206, 136-142.

Purvis, K. \& Haynes, N.B. (1974) Short-term effects of copulation, human chorionic gonadotropin injection and non-tactile association with a female on testosterone levels in the male rat. J. Endocr. 61, 241-253.
Resko, J.A., Feder, H.H. \& Goy, R.W. (1968) Androgen concentrations in plasma and testis of developing rats. J. Endocr. 40, 485-491.

Rohen, J.W. (1978) Der Einfluß des Kallikrein-KininSystems auf die Spermatogenese. Fortschr. Androl. 6, 16-25.

Schenck, B. (1980) Hormonale Regulation der Nebenhodenfraktion. In Physiologie und Pathophysiologie des Nebenhodens und der Samenblase, pp. 40-51. Eds Th. Senge, F. Neumann \& U. W. Tunn. Georg Thieme Verlag, Stuttgart.

Schill, W.B. \& Haberland, G.L. (1974) Kinin-induced enhancement of sperm motility. Hoppe-Seyler's $Z$. physiol. Chem., 335, 229-231.

Schweisfurth, H. \& Dahlheim, H. (1978) Determination of tissue converting enzyme and renal iso-converting activity. In Radioimmunoassay-Renin-Angiotensin, pp. 71-75. Eds D. K. Krause, W. Hummerich \& K. Poulsen. Georg Thieme Verlag, Stuttgart.

Setchell, B.P. (1974) Secretions of the testis and epididymis. J. Reprod. Fert. 37, 165-177.

Tuck, R.R., Setchell, B.P., Waites, G.M.H. \& Young, J.A. (1970) The composition of fluid collected by micropuncture and catheterization of fluid collected by micropuncture and catheterization from the seminiferious tubules and rete testis of the rat. Pflügers Arch. 318, 225-243.

Voglmayr, J.K. (1975) Metabolic changes in spermatozoa during epididymal transit. In Handbook of Physiology, Male Reproductive System, Vol. V, pp. 437-451. Eds R. O. Greep \& E. B. Astwood. American Physiological Society, Washington, D.C.

Wong, P.Y.D. \& Young, C.H. (1978) Absorptive and secretory functions of the perfused rat cauda epididymidis. J. Physiol., Lond. 275, 13-26.

Yang, H.Y.T., Erdoes, E.G. \& Levin, Y. (1971) Characterization of a dipeptide hydrolase (kininase II: angiotensin I converting enzyme). J. Pharm. exp. Ther. 177, 291-300.

Received 15 June 1981 